\title{
Training and career appointments in the pathological sciences in the United Kingdom
}

\author{
D. N. BARON \\ From the Department of Chemical Pathology, Royal Free Hospital, London
}

SYNOPSIS Pathologists usually receive initial training in clinical work, or in general pathology, or in academic work, followed by speciality training as a senior registrar or lecturer. Consultant status is generally achieved by the age of 34 , now almost always in a single discipline. The distribution of pathologists between disciplines, in National Health Service and university posts, is tabulated: there are many unfilled appointments.

A survey has been made of pathology training and career appointments, primarily of medical graduates, to provide information for the display of the Royal College of Pathologists at a forthcoming Medical Careers Fair, sponsored by the British Medical Association and by Update Publications. The information may be of interest to a wider audience.

Table I, which shows the recent staff situation in the National Health Service (NHS), is subject to an admitted margin of error in a continually fluctuating situation. The table excludes registrars and senior house officers. To those responsible for organizing the pathology services and the training of pathologists, the imponderable number is the 622 general pathologists, and also the surprisingly large number of senior registrars who are apparently Received for publication 18 September 1974.

\begin{tabular}{|c|c|c|c|}
\hline & Consultant & $\begin{array}{l}\text { Senior } \\
\text { Hospital } \\
\text { Medical } \\
\text { Officer/ } \\
\text { Medical } \\
\text { Assistant }\end{array}$ & $\begin{array}{l}\text { Senior } \\
\text { Registrar }\end{array}$ \\
\hline $\begin{array}{l}\text { General pathology } \\
\text { Histopathology } \div\end{array}$ & 572 & 50 & 50 \\
\hline $\begin{array}{l}\text { cytology } \\
\text { Haematology + blood }\end{array}$ & 181 & 11 & 50 \\
\hline transfusion & 179 & 35 & 71 \\
\hline Chemical pathology & 107 & 4 & 26 \\
\hline Medical microbiology & 206 & 8 & 30 \\
\hline Immunology & 9 & $\mathbf{0}$ & $\mathbf{0}$ \\
\hline $\begin{array}{l}\text { Advertised posts unfilled for } \\
\text { more than six months } \\
\text { (all subjects, histopathology } \\
\text { is least affected) }\end{array}$ & 50 & - & 35 \\
\hline
\end{tabular}

Table I National Health Service medical appointments (1973) in the 670 pathology laboratories in the United Kingdom appointed to be trained and to work in all subjects. To plan the future of pathology it will be necessary to obtain up-to-date information on the proportion of time that these general pathologists spend in the different disciplines, and on how their future replacement, probably by single-discipline pathologists, is envisaged locally. In his thorough survey 'Manpower in Pathology 1969-1975', based on 1969 figures, Greenbury (1971) stated that $52 \%$ of all regional board pathologists devote $90 \%$ or more of their time to a single speciality.

The majority of trainees have obtained a consultant appointment, taking all disciplines of pathology together, by the age of 34: the median age of obtaining Membership of the Royal College of Pathologists is 32 years (see fig). At what stage could a trainee in pathology (and in other subjects), by virtue of experience and attainment, become a specialist before becoming a consultant by virtue of obtaining a specific appointment?

There are in NHS pathology laboratories about $\mathbf{7 5}$ top grade scientists (consultant status), and 180 principal grade scientists, almost all of whom work as clinical biochemists.

Table II, which shows the recent university staff situation, is based on the Commonwealth Universities Handbook (1973) which is inconsistently classified and probably incomplete. Table II excludes assistant lecturers/demonstrators and research fellows. There are some pathologists nominally in other department, such as haematologists in medicine and immunologists in rheumatology. No numerical information is available on unfilled posts, but it is well known that academic posts, 'especially lectureships, are becoming hard to fill, and there are vacancies, except perhaps in histopathology. When 


\begin{tabular}{|c|c|c|c|c|}
\hline Post & Professor & Reader & $\begin{array}{l}\text { Senior } \\
\text { Lecturer }\end{array}$ & Lecturer \\
\hline \multicolumn{5}{|l|}{$\begin{array}{l}\text { Experimental } \\
\text { pathology including }\end{array}$} \\
\hline $\begin{array}{l}\text { Forensic medicine, etc } \\
\text { 'Pathology' including }\end{array}$ & $2+0$ & $2-0$ & $5-3$ & $5 \div 0$ \\
\hline & $54 \cdots 1$ & $32-1$ & $81-1$ & $109-11$ \\
\hline Haematology, etc & $14-0$ & $9 \ldots 0$ & $24 \div 1$ & $19+2$ \\
\hline $\begin{array}{l}\text { Chemical pathology, } \\
\text { including biochemica } \\
\text { endocrinology, etc }\end{array}$ & $\stackrel{\mathrm{al}}{ } \textrm{ }$ & $4-9$ & $31-13$ & $20 \therefore 30$ \\
\hline $\begin{array}{l}\text { Medical microbiology } \\
\text { including parasitolog }\end{array}$ & & & & \\
\hline etc & $36+5$ & $22 \div 2$ & $47 \div 17$ & $56 \div 46$ \\
\hline Immunology, etc & $4+3$ & $4 \div 0$ & $6 \div 1$ & $5 \ldots 2$ \\
\hline
\end{tabular}

Table II Academic whole-time medical ( + non-medical) posts in universities and medical schools (1972)

${ }^{1}$ Non-medical oosts are shown in italics.

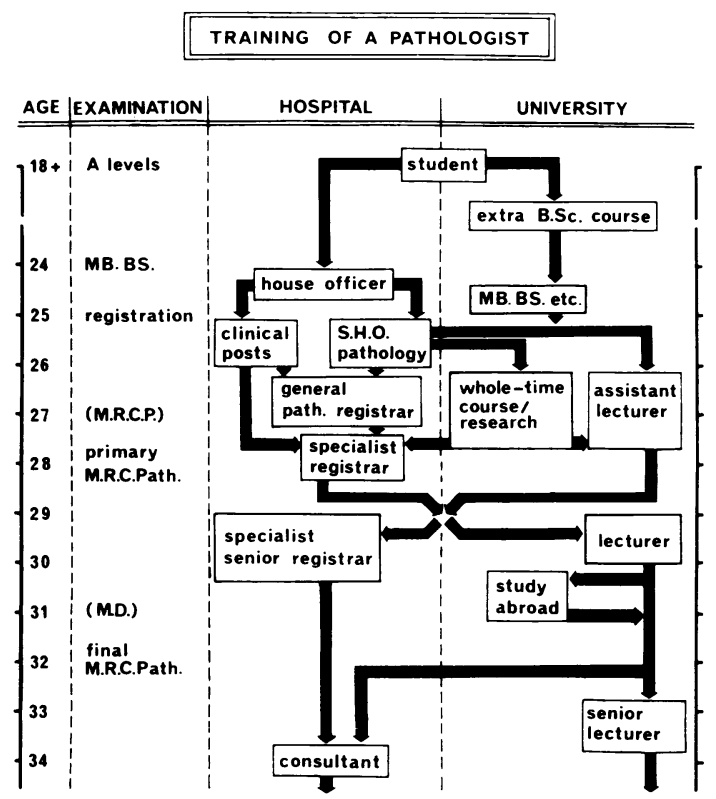

Fig Outline career flowchart for medical graduates training as pathologists in the United Kingdom.

considering appointments in pathology, it is necessary to look at tables I and II together, because movement in both directions between the NHS ladder and the university ladder during training is frequent at all levels - especially registrar $\rightarrow$ lecturer $\rightarrow$ consultant (seefig). Many NHS-employed pathologists have academic duties in undergraduate and postgraduate teaching: many university-employed pathologists have hospital duties in service laboratory supervision and patient care.

There are other sites of training and careers for pathologists. In the Public Health Laboratory Service there are (courtesy Dr R. E. O. Williams): 'consultant and SHMO status' 110 (+ 6 nonmedical), 'senior trainees' $20(+15$ non-medical $)$. Pathologists of all disciplines work in research institutes outside universities; for example, in the Imperial Cancer Research Fund Laboratories (courtesy Dr M. G. P. Stoker) there are about 20 'senior academic status' and 20 'senior trainees' (medical and non-medical combined). In addition there are pathologists in private practice, in the Armed Forces, in pharmaceutical companies and other industries, and elsewhere. Dental pathology and veterinary pathology must also be staffed by pathologists with appropriate training.

In the United Kingdom there are altogether about 2000 medically qualified pathologists (established posts, career grade), and about 350 non-medical scientists in pathology holding appointments of similar seniority. The membership in the Unitedo Kingdom of the Royal College of Pathologists is? about 2000 (Baron and Curran, 1973): not all career-grade pathologists are members, but membership includes many awaiting senior appointments. The continuing shortfall in pathologists is well known and is of grave concern (Lancet, 1974).

I should like to thank the Department of Health and Social Security, the Scottish Home and Health Department, with the Department of Health and Social Services (Northern Ireland), with Dr Sheila Waiter, and the Royal College of Pathologists with Professor Colin Campbell for much information. Mrs Anne Barrett (graphic artist) kindly drew the figure.

\section{References}

Baron, D. N., and Curran R. C. (1973). The objectives and functions of the Royal College of Pathologists. Hum. Path., 4, 149-150. Greenbury, C. L. (1971). Manpower in pathology 1969-1975. J. clin. Path., 24, 551-563.

Lancet (1974). 1, Editorial. Shortage specialties, 300-301. 